\title{
Complementary Freeze Fracture Methods Applied to Cattle Disk Membranes*
}

\author{
Akira Tonosaki, Masahiro Yamasaki, Hiroshi Washioka and Jiro Mizoguchi \\ Department of Anatomy (Prof. A. TonosAKI), Yamagata University School of Medicine, \\ Yamagata, Japan
}

Received July 5, 1979

Summary. The rod-outer-segment disk membranes were studied in cattle retinas by electron microscope observation of ultrathin resin sections and complementary freeze replicas. In sections, the membranes are characterized by discontinuous electron densities along the unit membrane structure, in which electron-less-dense globular substructures, forming an intermediate layer, are enhanced. Such substructures are estimated as $60 \AA$ in diameter. In freeze replicas, the membranous particles of $77 \AA$ in diameter are distributed quite densely in the $P$-face and scattered in the E-face. Like a number of preceding investigators who have failed to obtain convincing findings to correlate similar profiles with the visual pigment molecules, we should also raise a question about preparation involving chemical and thermal procedures affecting the dimensions of the final images.

Our constant results obtained from the two methods, however, will suggest that the thin-section substructures and freeze-replica particles represent two different phases respectively of the same molecular existence rather than a complete profile of the visual pigment. It is also uncertain yet whether one membranous particle should be in fact associated to one molecular pigment or an aggregation of several molecules. The last problem will be resolved to some extent by topographical analyses of the complementary replicas in progress in our laboratory.

Electron microscopists have paid attention to the irregular, globular substructures of the disk membranes of mammalian photoreceptors which appear in various thin sections (Nilsson,1964, 1965; Hirosawa, 1971; Rosenkranz, 1973; Nir and Hall, 1974; NIR and PEASE, 1975). Single or combined artifacts produced by fixation (CoHEN, 1971; Korenbrot, Brown and Cone, 1973; Jones, 1974), dehydration (Nir and Pease, 1973), staining (Godfrey, 1973) and/or sectioning (RoBERTson, 1966) have been examined as possible factors which might cause such globular images. Even though some distortions may possibly result from such different treatment, it seems likely that the disk membrane actually contains the globular substructure. These globular components have not been directly compared with freeze-fracture (FF) particles because both types of electron microscope images have not been fully trustworthy

\footnotetext{
* This work has been supported by the Science Research Grant of Japan, 157004, 177004, 187002, and 257001. A part of this work was presented in a poster session at the 3rd International Congress for Eye Research in Osaka, Japan, May 1978.
} 
yet (Tonosaki, Washioka and Mizoguchi, 1978). Nonetheless, their potential relationship should be explored.

Recently, remarkable progress has been made by analytic electron microscopy, in particular, the three-dimensional model of bacteriorhodopsin polypeptides (HENDERSON and UNWIN, 1975). The relationship between its single protein molecule, composed of seven $\alpha$ helices, and the subunits of purple membrane FF particles has been evaluated by Fisher and Stoeckenius (1977). In FF replicas image resolution and complementarity are reported to be enhanced by lowering the specimen temperature while maintaining the vacuum at $10^{-9}$ Torr (Gross, BAs and Moor, 1978). With regard to the morphology of an individual membrane particle, potential elastic and plastic deformations during FF procedure have been reviewed (SLEYTR and RoBARDS, 1977). The present paper will deal with the progress of complementary FF methods and the results obtained by the use of a simple device adapted to a conventional vacuum system (TonosaKi and Yamamoto, 1974; Yamamoto, Tonosaki and Watanabe, 1974). Remarkable textual non-complementarity is observed between comlementary fracture surfaces at higher magnification, in contrast to the complete matching of the cellular outlines. Terminology of plasmic fracture (PF) and exoplasmic fracture (EF) faces is employed after BRANTON et al. (1975).

\section{MATERIALS AND METHODS}

\section{Preparation}

Cattle eyes were obtained from freshly killed animals (160 eyes in total for 23 experiments) at the regional slaughterhouse, and stored in ice-cold physiological saline for 30-120 min for both epoxy-resin sections and FF specimens. The retinae were fixed for $24 \mathrm{hr}$ at $3^{\circ} \mathrm{C}$ with $2.5 \%$ glutaraldehyde in cacodylate buffer adjusted to $\mathrm{pH} 7.3$ (SABAtini, Bensch and Barrnett, 1963). For some FF specimens the retinae were fixed in phosphate-buffered glutaraldehyde at $\mathrm{pH} 7.4$ for $3-16 \mathrm{hr}$ at $3^{\circ} \mathrm{C}$ (MilloniG, 1962). Such alteration did not result in any recognizable variations of findings.

\section{Epoxy-resin sectioning}

The fixed retinae were further treated with 3.3\% osmium tetroxide solution adjusted to $\mathrm{pH} 7.3$ with cacodylate for $2 \mathrm{hr}$ at $3^{\circ} \mathrm{C}$. After dehydration with a graded ethanol series, the specimen was embedded in epoxy-resin (LuFT, 1961). All sections were mounted on carbon-coated micro plastic grids (FuKami and ADAchI, 1965), and stained with $2 \%$ uranyl acetate and saturated lead citrate (WATSON, 1958; REYNOLDS, 1963).

\section{FF instruments and procedures}

Prior to FF experiments, the specimens were cut into rectangular pieces $2 \times 8 \mathrm{~mm}^{2}$ and incubated in the fixative containing $30 \%$ glycerol for $3 \mathrm{hr}$ at $0^{\circ} \mathrm{C}$. The strip of retina was then placed in the specimen holder (Fig. 1,2) and frozen with liquid nitrogen without preliminary freezing with other coolant. The complementary FF device consisting of the specimen holder and cooling socket was used (ToNosAKI and Yамамото, 1974). It has been modified in this laboratory to protect the specimen holder from frost during the transfer from the nitrogen bath onto the stage of the 
evacuator and preliminary pumping. A copper cover was placed over the cooling socket while it was in nitrogen and was removed after $10^{-4}$ Torr was reached. The covered parts were thus kept clean throughout the preparation. The thermal stability of the device is shown in the graph (Fig. 2). The specimen underwent fracturing at the lowest temperature $\left(-160^{\circ} \mathrm{C}\right)$ at $1-3 \times 10^{-6}$ Torr ater $30 \mathrm{~min}$ of evacuation. The device was adapted to a conventional evacuator with a simple 4-inch- $\phi$ oil diffusion pump and liquid nitrogen-cold trap (Fig. 3). Evaporation of platinum

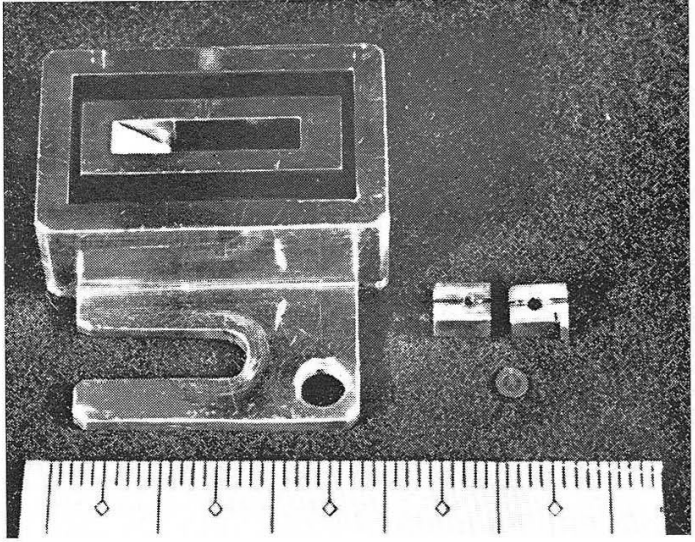

Fig. 1. Cooling socket, left, and parts of specimen holder, right. A specimen grid, $3 \mathrm{~mm}$ in diameter, is shown for scaling.
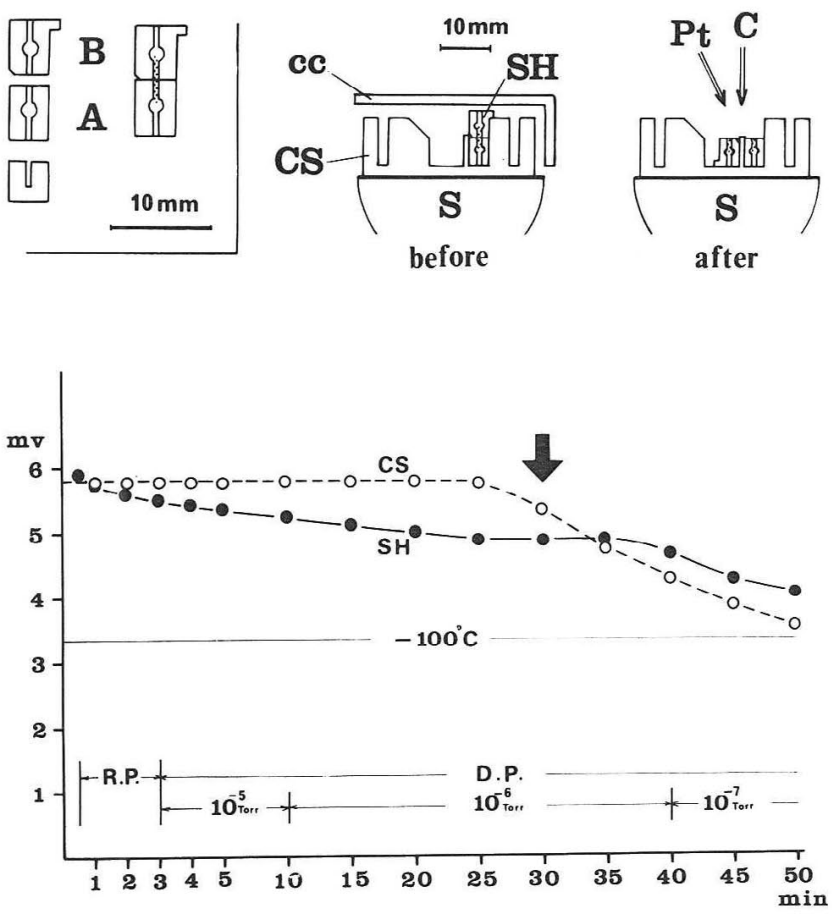

Fig. 2. Specimen holder $(\mathrm{SH})$, before and after fracturing, inside the cooling socket (CS), adapted to the cold stage $(S)$ of the evacuator. The parts of $S H, A$ and $B$, are detailed on the left. $C$ carbon source, $c c$ copper cover, $P t$ platinum source. Graph: Thermal stability of SH and CS after initial cooling to liquid- $\mathrm{N}_{2}$ temperature measured with thermocouple inserted and held in the position of $S H$ in the course of evacuation without addition of coolant. D.P. high vacuum phase with diffusion pump, R.P. preliminary phase with rotary pump. Note $S H$ maintained at $4.9 \mathrm{mV}$ or $-160^{\circ} \mathrm{C}$ around the time of fracturing $(\nearrow)$. 


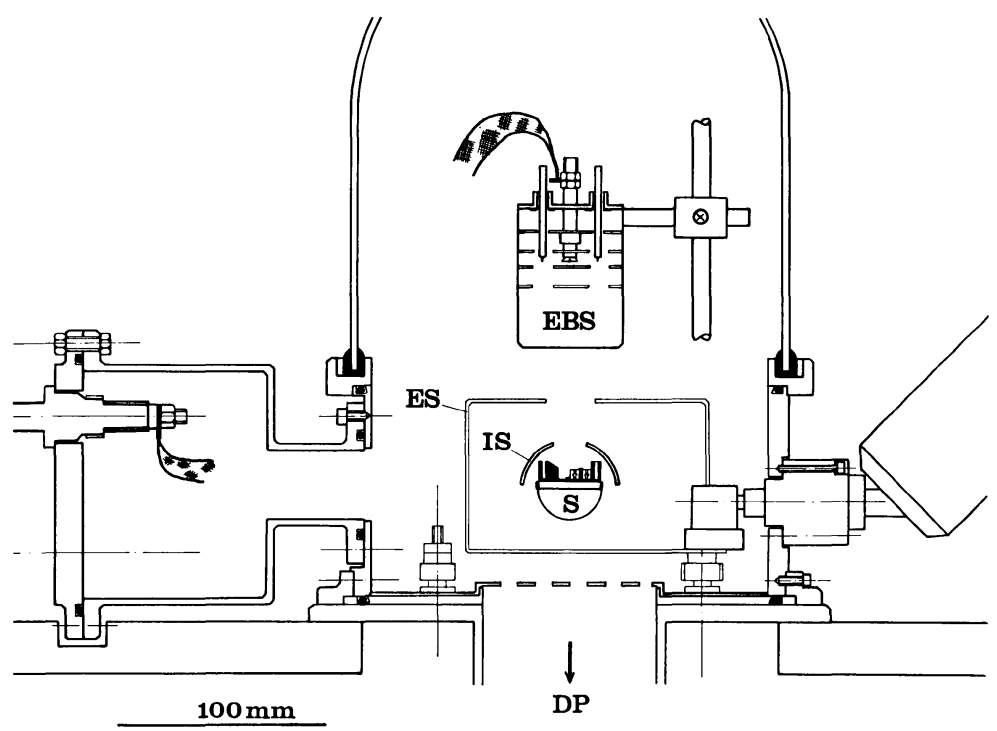

Fig. 3. Schematic diagram of complementary freeze-fracture device situated in the evacuator equipped with Twin Hearth Electron Bombarded Source $(E B S) . \quad D P$ diffusion pump, ES external shutter, IS internal shutter, $S$ specimen stage of evacuator.

and carbon was made using the Twin Hearth Electron Bombarded Source (Edwards High Vacuum, The British Oxygen Co., Crewley, England). Direct current $(3 \mathrm{kV}$, $50 \mathrm{~mA}$ ) was applied for 7-10 sec for Pt shadowing during which time a stripped tip of $1 \mathrm{~mm} \phi$ wire embedded in the carbon rod was evaporated. For C backing, $4 \mathrm{kV}$ and $50 \mathrm{~mA}$ were used for $12 \mathrm{sec}$, and the tip of $1 \mathrm{~mm} \phi$ rod was spent. The specimen halves carrying $\mathrm{Pt}-\mathrm{C}$ replicas were rinsed in absolute ethanol at room temperature, which reduced deformative forces exerted in thawing the tissues. After $60 \mathrm{~min}$ of cleaning in sodium hypochlorite and distilled water, the replicas were scooped up with 250 or 300 mesh copper grids.

Using our device, the vertically-laid retina was transversely fractured and the two halves were arranged back to back with the fractured faces oriented horizontally. A gap of $6 \mathrm{~mm}$ between two halves was considered small enough to produce roughly equivalent shadowing angles for both specimens for the shadowing distance of $115 \mathrm{~mm}$, and for angles of $80^{\circ}$ for shadowing and $90^{\circ}$ for backing.

\section{Electron microscopy}

A JEOL-200B-ASID electron microscope was used at accelerating voltage of $150 \mathrm{kV}$ for replicas, and $200 \mathrm{kV}$ for epoxy sections. All of the specimen grids were mounted on a specimen carrier specialized for horizontal rotation which permitted precise matching of the orientation between complementary replicas and stereoscopic pairs. A goniometer was also used for inclination. The beam current was set at 100-110 $\mu \mathrm{A}$ and the spot size was $2 \mu \mathrm{m} \phi$. An object aperture of $120 \mu \mathrm{m} \phi$ was regulary used. 


\section{OBSERVATIONS}

The cattle rod outer segment is uniform in shape and size, and is about $18.0 \mu \mathrm{m}$ in length and $1.5 \mu \mathrm{m}$ in diameter as measured on electron micrographs of thin sections. The disk membrane, when observed at higher magnifications, resembles a beaded string. Its thickness is approximately $60.5 \AA$ (Fig. 4). The staining heavy metals arc deposited onto the outer and inner leaflets forming discontinuous lines. Electron lucent to moderately opaque globular substructures, about $60 \AA$ in diameter, are prominent especially near the periphery of disks. The microvillous plasma membrane of the pigment epithelial cell, on the other hand, appears as a continuous, trilaminar unit membrane composed of heavily stained outer and inner leaflets (ca $30 \AA$ in thickness) separated by a continuous middle stratum (ca $28 \AA$ ) with an overall thickness of $88 \AA$ (Fig. 4, PM).

When the outer segments are laid slanting across the fracturing line of the specimen holder, they are fractured nearly-transversely (Fig. 5). The disks thus exposed on the replica have a diameter of $1.5 \mu \mathrm{m}(\mathrm{N}=51)$ which is in good approximation with the figure obtained from thin sections. The pair of membranes limiting a disk are distinguished as an unit of $\mathrm{PF}$ and $\mathrm{EF}$ faces separated by a narrow intradisk
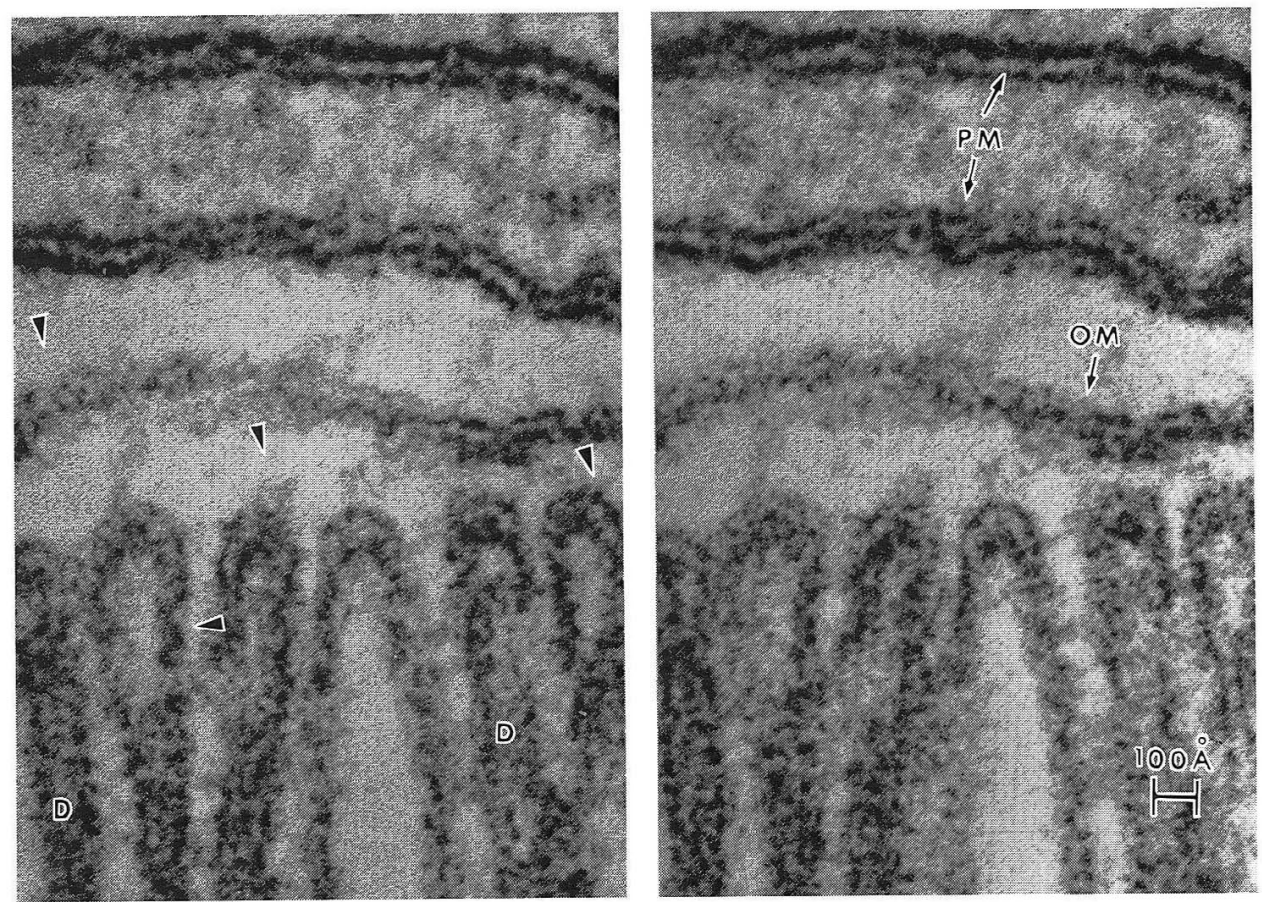

Fig. 4. Stereoscopic high-power view of a thin section of cattle outer segment, arranged for unaided cross vision. Sudstructures are indicated with arrowheads. $D$ disk membrane, $O M$ plasma membrane of outer segment, $P M$ plasma membrane of the pigment epithelial cell process. $\times 600,000$ 
space (Fig. 6). The PF face is characterized by $77 \mathrm{~A}$ diameter particles $(\mathrm{N}=342)$ as measured with the criteria applied to the purple membrane (FISHER and STOEckenius, 1977). The density of the particles is $31.7 / 10^{-6} \AA^{2}$ on the average. The free edge of the PF face is remarkably serrated with a series of projections extending out over vertical cliffs of the underlying interdisk cytoplasm (Fig. 7, arrows). The EF face which has been often described as smooth or particle-free is in fact characterized by sporadic particles with densities of $1.3 / 10^{6}$ or $9.0 / 10^{6} \AA^{2}$ in randomly selected areas. Such textures are often characterized as a cobblestone pattern, particularly at low shadowing angles (Fig. 5). The EF face does not present adequate numbers of depressions to receive the PF particles. Only uniquely shaped aggregations of particles can be correlated with their complementary counterparts (Fig. 7).

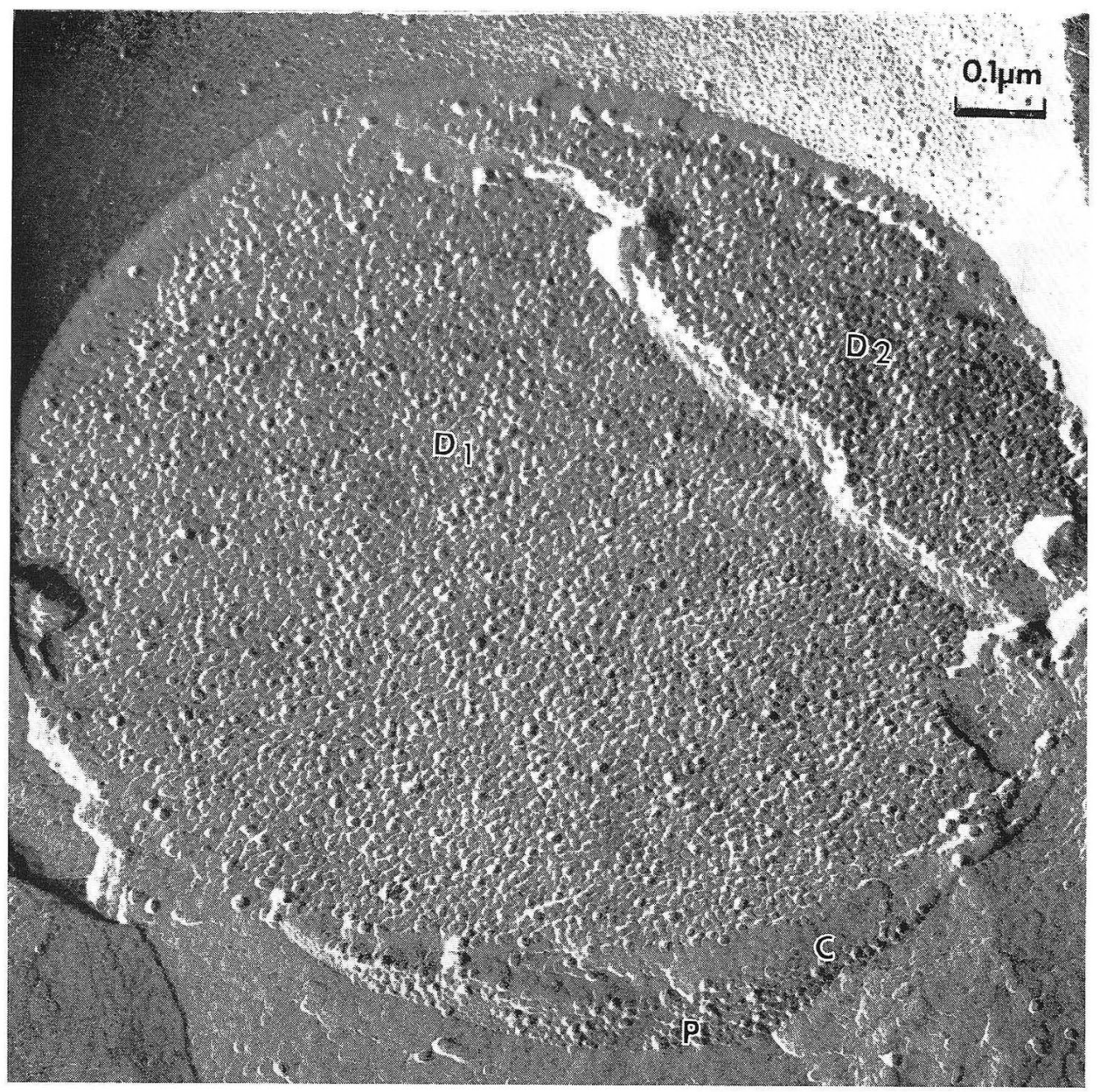

Fig. 5. Typical FF faces containing an entire cross section of a rod outer segment. A small part of PF face of the plasma membrane $(P)$, cytoplasm $(C)$, and PF faces of two neighboring disks $\left(D_{1}, D_{2}\right)$ are distinguished. $\times 100,000$ 

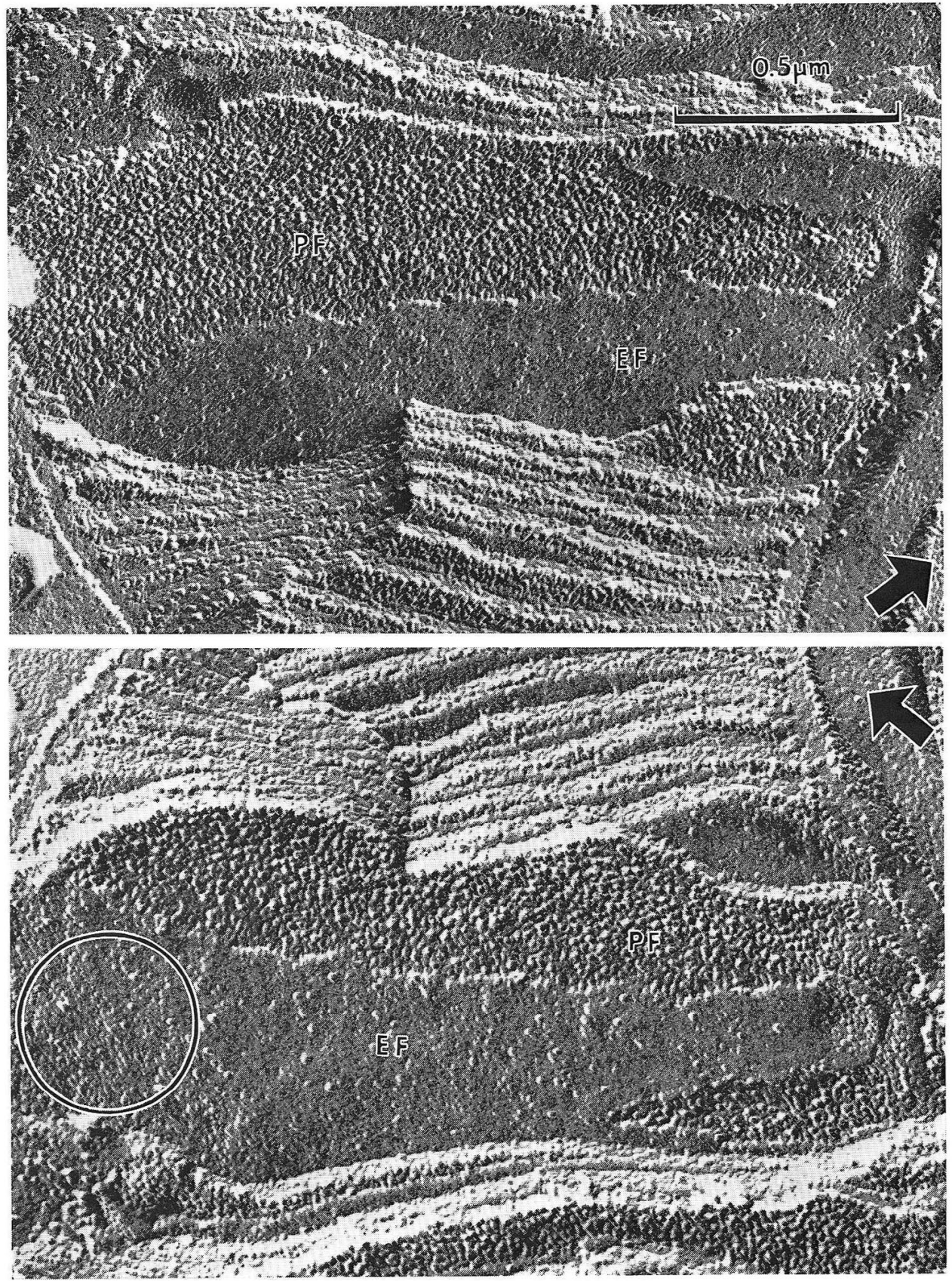

Fig. 6. Complementary replicas from a fractured disk. Note different surface density of bumps in the EF face depending upon its orientation towards the shadowing source (encircled area). Marked faces in this figure are those of two membranes belonging to a single disk. $\times 60,000$ 


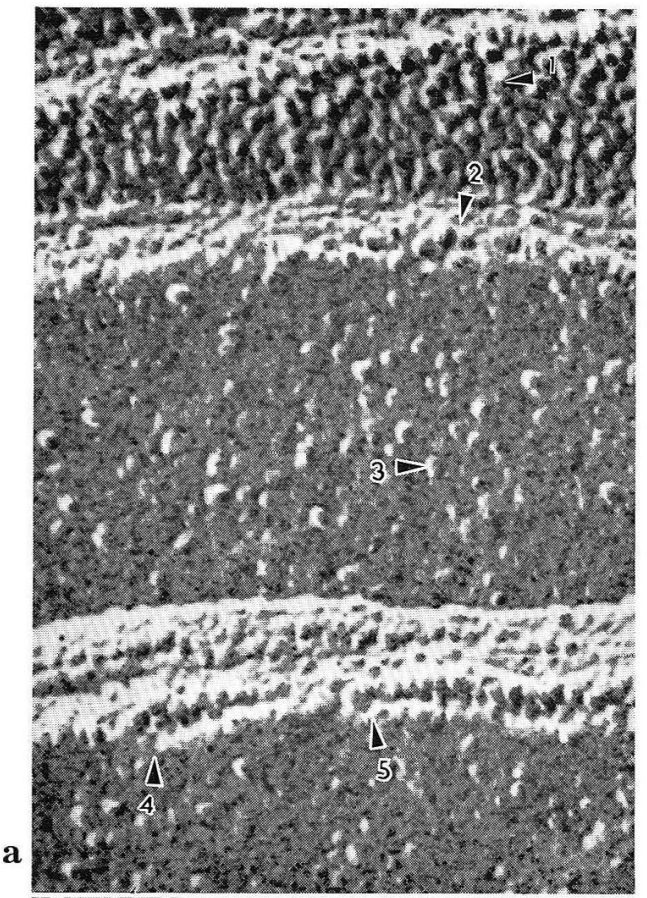

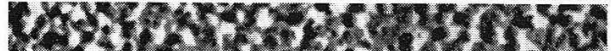

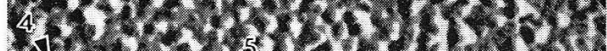

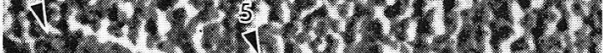

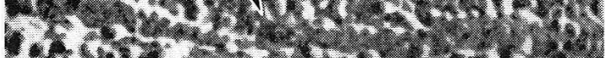

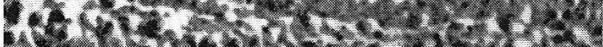
iy

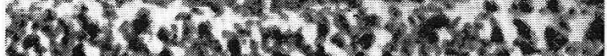

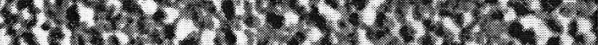
Xthis

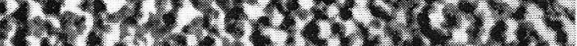

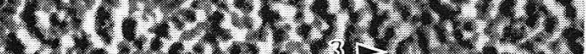

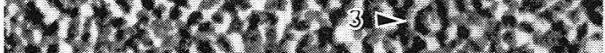

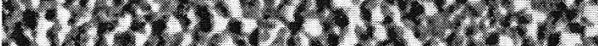
10.6)

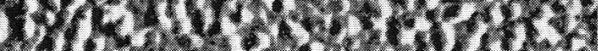

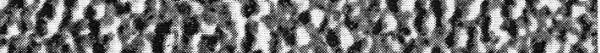

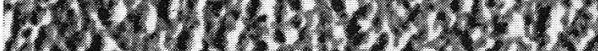
If

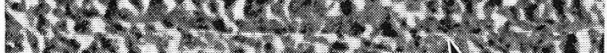
3.

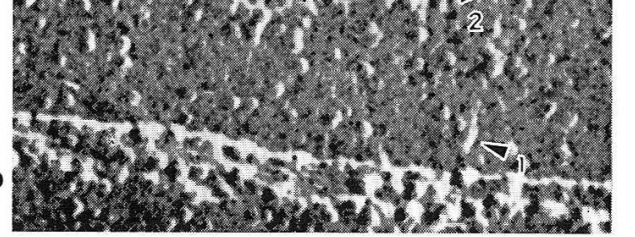

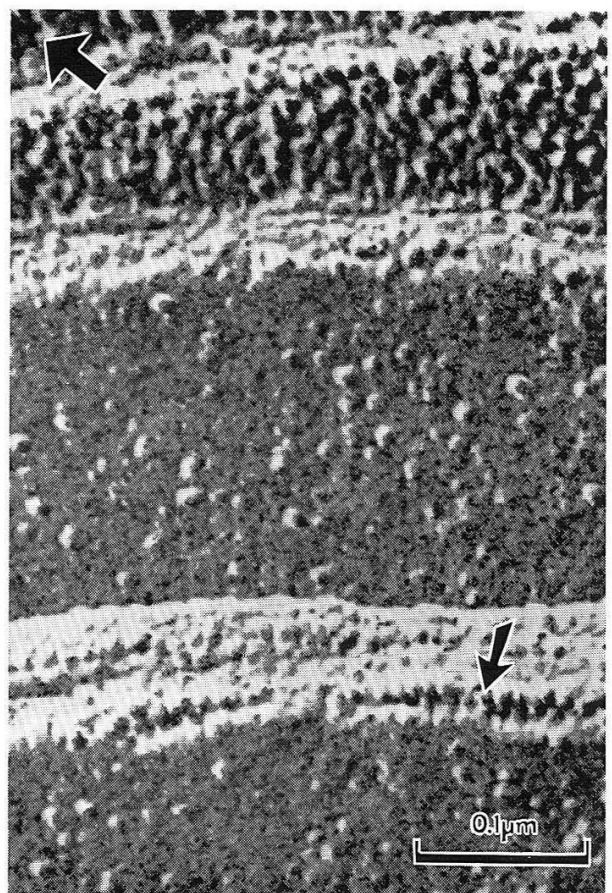

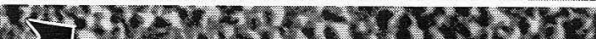

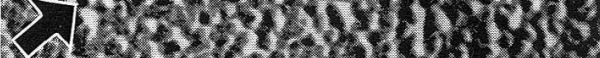

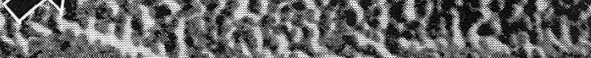

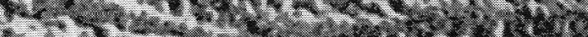

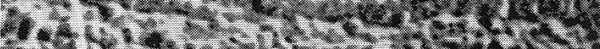
2.

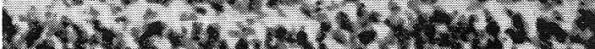

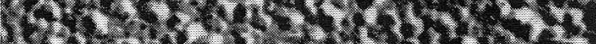

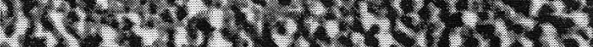

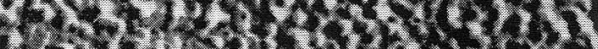

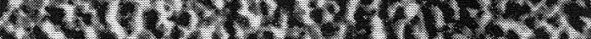

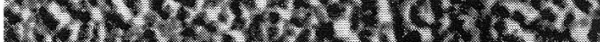

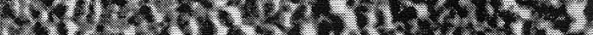
(3)

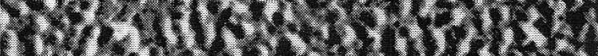

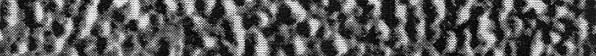

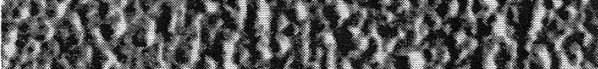

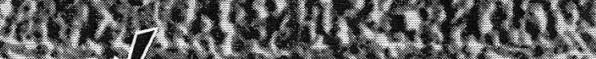

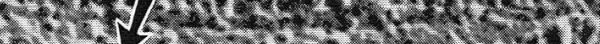

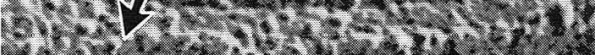

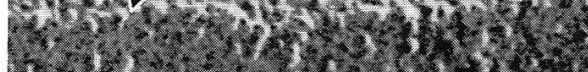

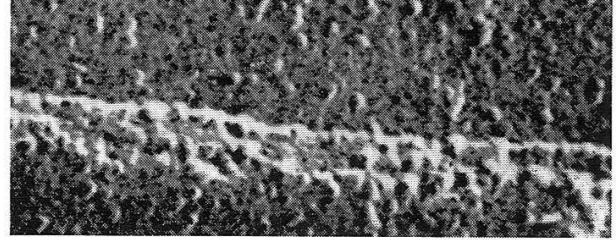

Fig. 7. a and b. Stereographs of complementary PF, EF, and fracturing edges of cattle disks, arranged for unaided cross vision. Major topological relationships are almost self-evident. Correlations between surface details are made by tracing certain landmarks one by one as indicated by the numerical sequence. Note the serrated, free edges $(\nearrow)$. 


\section{DISCUSSION}

In the preparation of specimens embedded for thin sectioning, considerable molecular rearrangements presumably occur within biological membranes regardless of the exact preparatory method employed. It seems most probable that the globular substructures represent the proteins surrounded by lipid aggregations, all of which are stained en masse by heavy metals. Since FF procedures appear to involve less drastic treatments, they may preserve more information of molecular arrangement. It is thus important to determine whether a PF particle represents one protein molecule plucked off the outer leaflet, or a mass of molecules resulting from the collapsed lipids and proteins. In the Halobacterium purple membrane (FISHER and STOECKENIUS, 1977), omatidial rhabdomeric membrane (YAMADA and UsukURA, 1978) and darkadapted frog disk membrane (Olive and Recouvreur, 1978), the PF particles have been described to be packed so densely that they form remarkable geometric arrays. In cattle we have failed to find $\mathrm{PF}$ particles organized with such a high degree of regularity, as shown with optical diffraction methods. The higher lipid content, $40 \%$ in vertebrate disk membranes compared with $25 \%$ in the purple membrane (Blaurock, 1972), may restrict the size of clustering PF particles.

According to the recent hypothesis that rhodopsin is spindle-shaped, $75 \AA$ or more in length, and penetrating the membrane transversely, its diameter should be considerably less than $40-45 \AA$, as estimated for a spherical molecule of $28,000-40,000$ Dalton molecular wt (Wu and Stryer, 1972; Raubach, Nemes and Dratz, 1974). On the other hand, the molecular conformation of the membrane phospholipids has been defined as a hydrocarbon chain with a van der Waals cross section of $5 \AA$ diameter (BENnETT, 1975). The PF particles, which have a wide range of diameters (e.g., $77 \AA$ in cattle), may represent protein-lipid complexes rather than specific protein molecules. A report that rhodopsin loses its regenerability upon the complete removal of the associated phospholipids (ZORN and FUTTERMAN, 1971) would emphasize structural associations between the protein and lipids. Such interactions in no way imply a rigid architecture that might impede lateral diffusion of rhodopsin in the plane of the disk membrane (Poo and Cone, 1974). On EF faces, there is no compelling evidence for deep holes which should be present if proteins have been removed. The only possible explanation for this fact may be that such a hole is either deformed by rearrangement of lipids (CoRLEss et al., 1976) or made shallow by shadowing effects.

As shown in several types of synthetic materials (SLEYTR and Robards, 1977), elastic and plastic deformations may produce significant changes in FF surfaces. Resolution of fine structure including such post-fractured changes will become complete only through some complementary FF methods. Clean complementary surfaces can be obtained by fracturing in a high vacuum, using either hinged (STEERE and Moseley, 1969; Mühlethaler, Wehrl and Moor, 1970) or unhinged devices (Wehrli, Mühlethaler and Moor, 1970; Tonosaki and Yamamoto, 1974). It is probably not advisable for high resolution to transfer FF specimens into a bell jar after preliminary fracturing outside (Chalcroft and Bullivant, 1970; Sleytr, 1970) because of possible contaminating deposits during pumping. Our complementary methods have here proved that the specimen holder will be adaptable to a variety of 
tissue or cell preparations, with good reliability and reproducibility. It has been recently emphasized that the quality of an $\mathrm{FF}$ replica depends upon the extent to which one can maintain a high vacuum and a low temperature during the the procedure (Gross, BAs and Moore, 1978). We are currently planning to incorporate such considerations to further improve our apparatus. Our efforts in this regard will be the subject of a future report.

Acknowledgement. The authors are grateful to Dr. Duco Hamasaki, Eye Institute, University of Miami School of Medicine, and Prof. Toshi Yuki Yамамото, Department of Anatomy, Tohoku University School of Medicine, for their advice on the manuscript.

\section{双面凍結レプリカ法のウシ円板膜への応用}

外崎 昭, 山崎正博, 鷲 岳 宏, 溝口二 郎

ウシ網膜の杆状体細胞外節円板膜を，薄切樹脂切片と双面凍結レプリカの電顕観察により 研究した。薄切法においては，円板膜がそのユニット膜構造に沿って不連続的暗調部を 示し，その結果，中間層を形成する やや朋調な小球状構造が顕著に認められる。 それら の直径は約 $60 \AA$ と見積られる. 一方, 凍結レプリカ法においては, 直径 $77 \AA$ の膜粒子が $\mathrm{P}$ 面には密に, E面には散在性に分布する.すでに多数の研究者たちが 上記のような電顕 像を視物質分子に結びつける十分な所見を得ることに失敗しているが，われわれもまた 化学的ないし熱的過程を含む試料作製過程が，これら最終電顕像の形状に影響を与えてい るのではないかと疑わざるを得ない。

しかし，われわれが異なった 2 方法によって得た再現性の高い結果は，薄切切片上の小 球状構造と凍結レプリカ上の粒子とが，視物質の完全な姿よりはさしろ，同一の分子的実 在の相異なる形相にそれぞれ対応することを暗示するであろう。また 1 個の膜粒子が 果 たして 1 個の分子的視物質に相当するか, あるいは数個の集合体に相当するかの問題も依 然として不明である.この最後の問題は，目下われわれが行なっている双面レプリカの局 所地形学的分析によって一定の限界まで解決されるであろう.

\section{REFERENCES}

Bennett, H. S.: The dimensions of polar lipids of membranes. In: (ed. by) E. Yamada: Proc. 10th Int. Congr. Anat. (Tokyo). Science Council of Japan, Tokyo, 1975 (p. 491).

Blaurock, A. E.: Locating protein in membranes. Nature 240: 556-557 (1972).

Branton, D., S. Bullivant, N. B. Gilula, M. J. Karnovsky, H. Moor, K. Mühlethaler, D. H. Northcote, L. Packer, B. Satir, P. Satir, V. Speth, L. A. Staehlin, R. L. Steere and R. S. Weinstein: Freeze-etching nomenclature. Science 190: 54-56 (1975).

Chalcrof t, J. P. and S. Bullivant: An interpretation of liver cell membrane and junction structure based on observation of freeze-fracture replicas of both sides of the fracture. J. Cell Biol. 47: 49-60 (1970). 
Cohen, A. I.: Electron microscope observations on form changes in photoreceptor outer segments and their saccules in response to osmotic stress. J. Cell Biol. 48: 547-565 (1971).

Corless, J. M., W. H. Cobbs, III, M. J. Costello and J. D. Robertson : On the asymmetry of frog retinal rod outer segment disk membranes. Exp. Eye Res. 23: 295-324 (1976).

Fisher, K. A. and W. Stoeckenius : Freeze-fractured purple membrane particles: protein content. Science 197: 72-74 (1977).

Fukami, A. and K. Adachi : A new method of preparation of a self-perforated micro plastic grid and its application (I). J. Electron Microsc. 14: 112-118 (1965).

Godfrey, A. J.: A study of the ultrastucture of visual cell outer segment membranes. J. Ultrastr. Res. 43: 228-246 (1973).

Gross, H., E. Bas and H. Moor : Freeze-fracturing in ultrahigh vacuum at $-196^{\circ}$ C. J. Cell Biol. 76: 712-728 (1978).

Henderson, R. and P. N. T. Unwin: Three-dimensional model of purple membrane obtained by electron microscopy. Nature 257: 28-32 (1975).

Hirosawa, K.: A preliminary note on the fine structure of the chloroform-methanol treated outer segment of frog retina. Arch. histol. jap. 33: 341-349 (1971).

Jones, G. J : Electron microscopy of frog photoreceptor outer segments after fixation with aldehydes. J. Cell Sci. 16: 199-219 (1974).

Korenbrot, J. I., D. T. Brown and R. A. Cone: Membrane characteristics and osmotic behavior of isolated rod outer segments. J. Cell Biol. 56: 389-398 (1973).

Luft, J. H.: Improvements in epoxy resin embedding methods. J. biophys. biochem. Cytol. 9: 409-414 (1961).

Millonig, G.: Further observation on a phosphate buffer for osmium solutions in fixation. In: Proc. 5th Int. Congr. Electron Microsc. (Philadelphia), 1962 (Vol. 2, p. 8).

Mühlethaler, K., E. Wehrli and H. Moor: Double fracturing methods for freeze-etching. In: Proc. 7th Int. Congr. Electron Microsc. (Grenoble), 1970 (p. 449-450).

Nilsson, S. E. G. : A globular substructure of the retinal receptor outer segment membranes and some other membranes in the tadpole. Nature 202: 509-510 (1964).

-: The ultrastructure of the receptor outer segments in the retina of the Leopard frog (Rana pipiens). J. Ultrastr. Res. 12: 207-231 (1965).

Nir, I. and M. O. Hall : The ultrastructure of lipid-depleted ROD photoreceptor membranes. J. Cell Biol. 63: 587-598 (1974).

Nir, I. and D. C. Pease : Ultrastructural aspects of discs in rod outer sements. Exp. Eye Res. 16: 173-182 (1973).

- : Substructure in rod photoreceptor membranes. Anat. Rec. 182: 15-28 (1975).

Olive, J. and M. Recouvreur: Freeze fracture features and molecular architecture of photoreceptor membranes. In: (ed. by) J. H. Kinoshita and T. Otori: Proc. 3rd Int. Congr. Eye Res. (Osaka), 1978 (p. 131).

Poo, M. and R. A. Cone: Lateral diffusion of rhodopsin in the photoreceptor membrane. Nature 247: 438-441 (1974).

Raubach, R. A., P. P. Nemes and E. A. Dratz: Chemical labeling and freeze-fracture studies on the localization of rhodopsin in the rod outer segment disk membrane. Exp. Eye Res. 18: 112 (1974).

Reynolds, E. S.: The use of lead citrate at high $\mathrm{pH}$ as an electron opaque stain in electron microscopy. J. Cell Biol. 17: 208-212 (1963).

Robertson, J. D.: Granulo-fibrillar and globular substructure in unit membranes. Ann. New York Acad. Sci. 137: 421-440 (1966).

Rosenkrantz, J.: New results on the ultrastructure of frog outer segments. Z. Zellforsch. 143: 45-52 (1973).

Sabatini, D. D., K. Bensch and R. J. Barrnett: Cytochemistry and electron microscopy. The preservation of cellular ultrastructure and enzymatic activity by aldehyde fixation. J. Cell 
Biol. 17: 19-58 (1963).

Sleytr, U.: Die Gefrierätzung korrespondierender Bruchhälften: neuer Weg zur Aufklärung von Membranstrukturen. Protplasma 70: 101-117 (1970).

Sleytr, U. B. and M. Robards: Plastic deformation during freeze-cleavage: a review. J. Microsc. 110: 1-25 (1977).

Steere, R. L. and M. Moseley : New dimensions in freeze-etching. In: Proc. 27th Ann. Meet. Electron Microsc. Soc. Amer., 1969. (p. 202-203).

Tonosaki, A., H. Washioka and J. Mizoguchi : Fine structure of the disk membranes by means of the complementary freeze-replica and ultrathin section. In: (ed. by) J. H. Kinoshita and T. Otori: Proc. 3rd Int. Congr. Eye Res. (Osaka), 1978 (p. 130).

Tonosaki, A. and T. Y. Yamamoto: Double-replicating method for the freeze-fractured retina. J. Ultrastr. Res. 47 : 86-94 (1974).

Watson, M. L.: Staining of tissue sections for electron microscopy with heavy metals. J. biophys. biochem. Cytol. 4: 475-478 (1958).

Wehrli, E., K. Mühlethaler and H. Moor: Membrane structure as seen with a double replica method for freeze fracturing. Exp. Cell Res. 59: 336-339 (1970).

Wu, C. -W. and L. Stryer: Proximity relationship in rhodopsin. Proc. Nat. Acad. Sci. U.S. A. 69: 1104-1108 (1972).

Yamada, E. and J. Usukura: Freeze-fracture replica studies on the photoreceptive membranes. In: (ed.) J. H. Kinoshita and T. Otori: Proc. 3rd Int. Congr. Eye Res. (Osaka), 1978 (p. 242).

Yamamoto, T. Y., A. Tonosaki and H. Watanabe: Complementrary faces of the rod disc membrane in freeze-fracture replicas. Tohoku J. exp. Med. 113: 313-317 (1974).

Zorn, M. and S. Futterman: Properties of rhodopsin dependent on associated phospholipid. J. biol. Chem. 246: 881-886 (1971).

外崎 昭

₹990-23 山形市藏王飯田

山形大学医学部

解剖学第一講座
Prof. Akira Tonosaki

Department of Anatomy, Yamagata University School of Medicine Yamagata, 990-23 Japan 